\title{
Distribution and abundance of aerobic anoxygenic phototrophic bacteria in the tropical coastal waters of Gunungkidul, Yogyakarta, Indonesia
}

\author{
VICTOR APRILYANTO ${ }^{1}$, LANGKAH SEMBIRING ${ }^{1}$, TJUT SUGANDAWATY DJOHAN ${ }^{2, \bullet}$ \\ ${ }^{1}$ Laboratory of Microbiology, Faculty of Biology, Universitas Gadjah Mada. Jl. Teknika Selatan, Sekip Utara, Sleman 55281, Yogyakarta, Indonesia \\ ${ }^{2}$ Laboratory of Ecology, Faculty of Biology, Universitas Gadjah Mada. Jl. Teknika Selatan, Sekip Utara, Sleman 55281, Yogyakarta, Indonesia. \\ Tel./fax.:+62-274-580-839. •email: tjutdjohan@ugm.ac.id
}

Manuscript received: 25 September 2020. Revision accepted: 28 October 2020.

\begin{abstract}
Aprilyanto V, Sembiring L, Djohan TS. 2020. Distribution and abundance of aerobic anoxygenic phototrophic bacteria in the tropical coastal waters of Gunungkidul, Yogyakarta, Indonesia. Biodiversitas 21: 5506-5513. Aerobic anoxygenic phototroph (AAP) is a community of bacteria capable of performing anoxygenic photosynthesis in the presence of oxygen. AAP abundance in most oceanic regions signals its ecological importance in marine microbial loop. This study was conducted to reveal the distribution and abundance of AAP in Siung coast, Gunungkidul, Yogyakarta, Indonesia. Total bacterioplankton and AAP were enumerated using acridine orange direct count (AODC) and real-time quantitative PCR (qPCR), respectively. Several water physicochemical parameters as well as dissolved nitrate, ammonium, phosphate, and sulfate were also measured. The results showed that total bacterioplankton was distributed thoroughly in the water column with abundance ranging from $2.5 \times 10^{4}$ to $3.5 \times 10^{4}$ cells $/ \mathrm{mL}$. Within this total bacterioplankton, AAP ranged from $3.83 \times 10^{2}-7.48 \times 10^{2}$ cells $/ \mathrm{mL}$, comprising about $1 \%$ to $\sim 2.5 \%$. Inorganic nutrient concentration, mainly nitrate and phosphate were thought to be the regulating factors to the distribution and abundance of both communities. In conclusion, AAP comprises a relatively low portion of the total bacterioplankton community in the tropical coastal water in Gunungkidul, Yogyakarta.
\end{abstract}

Keywords: Bacterioplankton, AAP bacteria, microbial loop, qPCR

Abbreviations: AAP: Aerobic anoxygenic phototrophic; AODC: Acridine orange direct count; bchl-a: Bacteriochlorophyll-a; qPCR: quantitative polymerase chain reaction

\section{INTRODUCTION}

Aerobic anoxygenic phototroph (AAP) is a group of bacteria capable to perform phototrophy while still relying on organic matter as the main carbon source (Yurkov 2006; Ferrera et al. 2011, 2017; Tang et al. 2011; Kirchman and Hanson 2013). Similar to their purple bacteria counterpart, AAP bacteria utilize photosystem-II which contains bacteriochlorophyll-a (bchl-a) to conduct cyclic photophosphorylation (Zheng et al. 2013). However, unlike the rest of purple bacteria, phototrophy in AAP bacteria could only operate in aerobic conditions due to their electron acceptor difference. The main electron acceptor in AAP bacteria is unique and present in reduced state during anaerobic conditions and therefore could not accept the electrons (Nagashima et al. 2014). Oxygen molecules are required to re-oxidize this reduced electron acceptor and maintain the process of photophosphorylation.

Most of the species in AAP bacteria are classified as a member of Alphaproteobacteria, while the others are in the Beta- and Gammaproteobacteria (Csotonyi et al. 2011; Boeuf et al. 2014). The most notable genera of marine AAP bacteria are Erythrobacter (Shiba and Simidu 1982) and Roseobacter (Shiba et al. 1991). Currently, 39 and 6 species are known as members of genera Erythrobacter (Erb) and Roseobacter (Rsb), respectively (Parte 2014, 2018).
However, not all of those species possess photosystem-II photosynthetic apparatus, hence not all of them belong to AAP bacteria. Species such as Roseobacter ponti (Jung et al. 2017), Roseobacter cerasinus (Muramatsu et al. 2020), Erythrobacter aquimixticola (Park et al. 2017), Erythrobacter arachoides (Xing et al. 2017), Erythrobacter insulae (Park et al. 2020) and Erythrobacter atlanticus (Zhuang et al. 2015) are several species from both genera which do not possess phototrophic trait and hence are suggester for genera reclassification (Hördt et al. 2020; Xu et al. 2020)

The ecological role of marine AAP bacteria was not really known until 2000, when it was discovered that photoheterotrophic ability might contribute to their survival in nutrient-poor marine environments, such as open ocean (Kolber et al. 2000; Kirchman 2018). Marine AAP bacteria abundance was firstly reported in 2001 where it contributes to $10 \%$ of total bacterioplankton in Pacific Ocean, implying its significant contribution towards global carbon cycle (Kolber et al. 2001; Ritchie and Johnson 2012). However, not all studies regarding AAP abundance were in agreement with it. Similar studies conducted on the off coast of Southern California and Mediterranean sea using real-time quantitative PCR (qPCR) reported that AAP comprises only $1 \%$ of total bacterioplankton (Schwalbach and Fuhrman 2005; Lamy et al. 2011; Graham et al. 2018). More studies of AAP bacteria across the oceans revealed a 
wide-ranging abundance, comprising of $1-16 \%$ in Atlantic (Cottrell et al. 2006; Sieracki et al. 2006), <5\% in North Pacific (Cottrell et al. 2006), 24\% in South Pacific (Lami et al. 2007), 10-14\% in Arctic (Boeuf et al. 2013), 1-8\% in Antarctic (Kirchman et al. 2014), 1-24\% in Adriatic Sea (Tomaš et al. 2019), as well as 5-25\% in Delaware estuary (Stegman et al. 2014). With such distribution and abundance data of AAP bacteria, it can be said that this community is distributed globally in the marine waters and made up a significant portion of total bacteria in the euphotic zone. These measurements on AAP abundance, however, had been conducted primarily on subtropical and temperate seas with some occasion in polar seas, but relatively lacking in tropical seas such as Indian ocean. Therefore, data concerning distribution and abundance of AAP bacteria in the tropical seas were scarce and so far, there had been no reports concerning the Indonesian tropical sea.

Siung is one of the southern coasts of Java located in Gunungkidul, Yogyakarta. In this study, we used real-time quantitative PCR analysis to assess the distribution and abundance of AAP bacteria in the water column of Siung coast. These data could provide insight in the ecological importance of AAP bacteria in the microbial loop as well as providing baseline data concerning the distribution and abundance of AAP bacteria in Indonesian sea.

\section{MATERIALS AND METHODS}

\section{Study site}

Siung coast is one of many coasts in Gunungkidul area of southern Java island, Indonesia. It lies next to Nglambor coast and can be reached from the nearest town, Wonosari. Geographically Siung coast is located in the equatorial zone and experiences only dry and wet season alternating every six months. Just like all coasts in southern Java,
Siung coast is a part of shelf sea ecosystem (Spalding et al. 2007). Samples were collected from the coastal zone of Siung (8'11'05.98'E; 11040'47.09' S) about 1 kilometer from the coastline during early dry season in May 2012 (Figure 1). The maximum and Secchi depths of the study site were 22 and 7 meters, respectively. Four determined sampling points were $0,4,6$, and 20 meters, representing surface, subsurface, light compensation, and near-bottom depths, respectively. Water samples were collected from four depths: $0,4,6$, and 20 meters in the water column using modified 2-liter-Van Dorn water sampler with five replicates. The samples were stored in the $600 \mathrm{~mL}$ sterile dark polystyrene bottles. Fifty $\mathrm{mL}$ of these samples were stored in polypropylene tubes and formaldehyde $37 \%$ was added into each tube until reaching $1 \%$ of the final concentration. Another $200 \mathrm{~mL}$ from each water sample was directly filtered through $0.2 \mu \mathrm{m}$-pore-size polycarbonate filters. All the filters were then stored in bead tubes and kept at $-20^{\circ} \mathrm{C}$ until DNA extraction. Filtrate from replicates of each depth was composited, stored into sterile dark polystyrene bottles, and kept in $-20^{\circ} \mathrm{C}$ until further analyses.

\section{Physicochemical parameters}

Along with the sampling from each depth, several physicochemical parameters were also taken. The parameters were comprised of water temperature, Secchi depth, salinity, alkalinity, $\mathrm{pH}$, and dissolved oxygen. Inorganic nutrients comprising of nitrate, ammonium, phosphate, and sulfate were also measured from water samples. Measurement of dissolved oxygen was conducted using Winkler method, while concentration of inorganic nutrients in the water was measured using spectro-photometric methods, comprising ascorbic acid reduction for nitrate, phosphomolybdate complex formation for phosphate, and atomic absorption spectroscopy for iron (Rand et al. 1976).
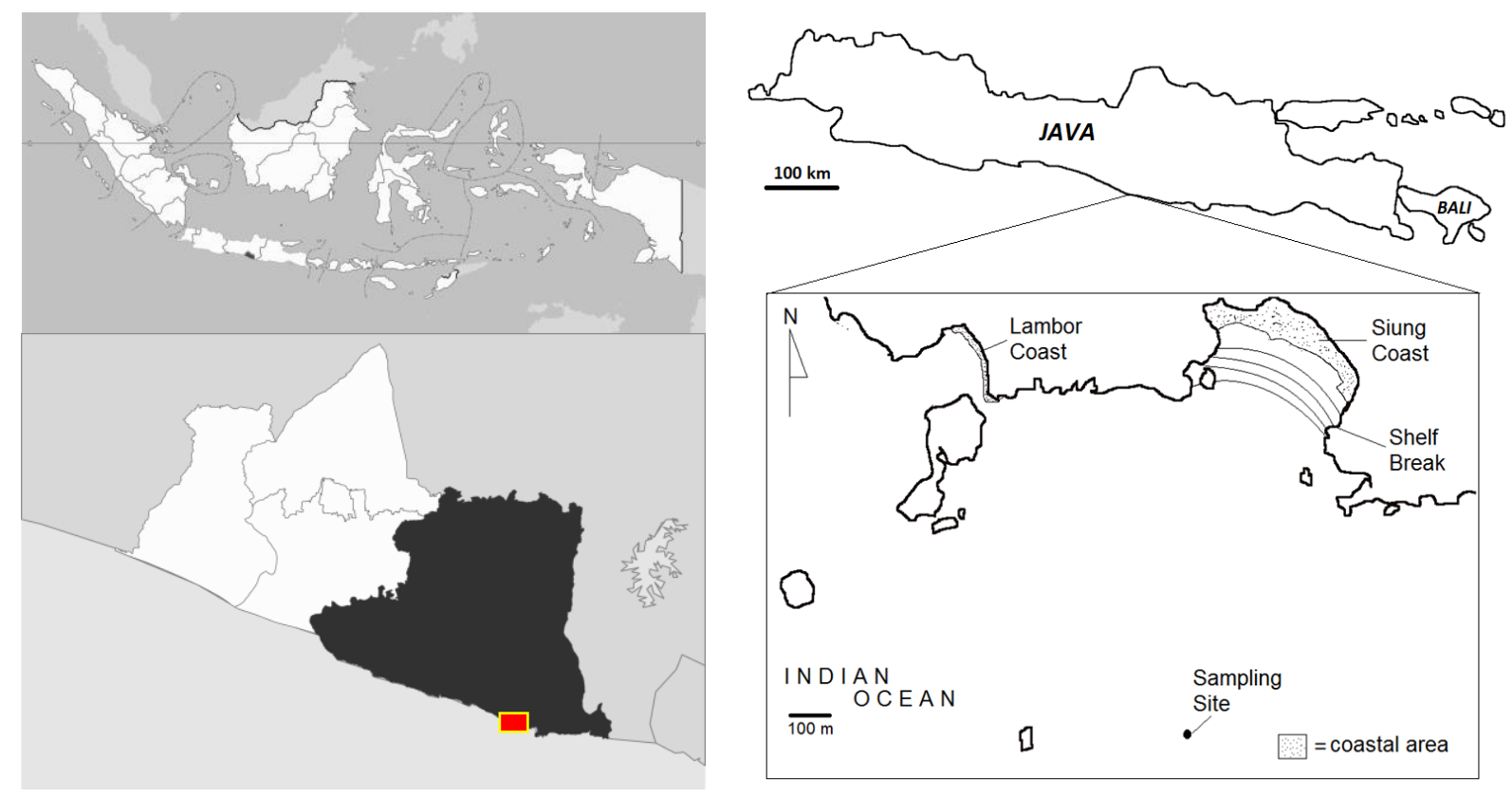

Figure 1. Sampling site at Siung coastal zone, Gunungkidul District, Yogyakarta, Indonesia 
All the nutrient concentration measurements were taken at the Laboratory of Chemistry, Faculty of Mathematics and Sciences, Universitas Gadjah Mada, Yogyakarta, and Health and Calibration Laboratory Center (Balai Laboratorium Kesehatan dan Kalibrasi), Yogyakarta.

\section{Enumeration of total bacterioplankton}

Total bacterioplankton is enumerated using acridine orange direct count (AODC) technique with some modifications (Ruyitno 1988). A $2.29 \mathrm{~mL}$ of acridine orange $1 \%$ solution was added to $5 \mathrm{~mL}$ water from each sample and incubated for at least 48 hours. Each sample was filtered through $0.2-\mu \mathrm{m}$-pore-size black polycarbonate filter (Millipore). After filtering, each filter was placed on top of a glass slide, stacked by cover glass, and given a drop of immersion oil on the top of the deck glass. Enumeration was conducted on sums of ten random field of views and the number of bacterioplankton were calculated by the following formula:

$$
\text { cell } / m l=n \times \frac{A_{1}}{A_{2}} \times \frac{1}{V}
$$

Where; $n$ : cell average count; $\mathrm{A}_{1}$ : area of the filter paper in contact with water sample $\left(490.87 \mathrm{~mm}^{2}\right) ; \mathrm{A}_{2}$ : microscope field of view area at $1000 \mathrm{x}$ magnification $\left(0.02405 \mathrm{~mm}^{2}\right)$; V: volume filtered water sample. One-tail LSD using Agricolae (R-package) was conducted to test the significance of total bacteria differences among depths.

\section{Enumeration of AAP bacteria}

AAP bacteria were enumerated by real-time quantitative PCR (qPCR) on extracted total DNA. Extraction of total DNA was conducted using bead-beating approach towards polycarbonate filters using Power Water DNA extraction kit (Qiagen, Germany). The extracted total DNA (Table S1) was then quantified for its pufM gene by quantitative real-time PCR (qPCR; BioRad CFX 96) using primer pairs $\operatorname{pufM(\mathrm {F})} 5$ '-CCATSGTCCAGCGCCAGAA3' and pufM(R) 5'-TACGGSAACCTGTWCTAC-3' (Achenbach et al. 2001; Béjà et al. 2002). The PCR composition proceeds as follows: 12,5 $\mu \mathrm{L}$ SsoFast ${ }^{\mathrm{TM}}$ Evagreen ${ }^{\circledR}$ Supermix (Bio-Rad, USA); $11 \mu \mathrm{L}$ PCR grade $\mathrm{H}_{2} \mathrm{O} ; 0,25 \mu \mathrm{L}$ of each primer $(40 \mu \mathrm{M})$, and $1 \mu \mathrm{L}$ DNA template $(2,5 \mathrm{ng} / \mu \mathrm{L})$. The following PCR thermal profile is $3^{\prime}$ in $95^{\circ} \mathrm{C}$ followed by 50 cycles of $30 \mathrm{~s}$ in $60^{\circ} \mathrm{C}$. The resulting $\mathrm{C}_{\mathrm{q}}$ value from each sample was then converted into initial puf $\mathrm{M}$ template number $\left(\mathrm{C}_{0}\right)$ using the standard curve from $\mathrm{Du}$ et al. (Du et al. 2006) according to the formula:

$$
A A P B / m l=\frac{C_{0} \times D N A_{A} /_{D N A_{B}} \times V_{D N A}}{V_{\text {water }}}
$$

Where; $\mathrm{C}_{0}$ : initial template number, DNAA: stock DNA concentration $(\mathrm{ng} / \mu \mathrm{L}), \mathrm{B}$ : DNA amount used in qPCR (ng), $\mathrm{C}$ : total volume of extracted DNA $(\mu \mathrm{l}), \mathrm{V}$ : total vol of filtered water $(\mathrm{mL})$. The corresponding $1: 1$ ratio of $\mathrm{C}_{0}$ :AAP was used to convert the initial template number to the number of AAP bacteria cells (Schwalbach and Fuhrman 2005).

\section{RESULTS AND DISCUSSION}

Distribution and abundance of total bacterioplankton

Siung coast contains total bacterioplankton ranging from $2.5 \times 10^{4}$ to $3.5 \times 10^{4}$ cells $/ \mathrm{mL}$ seawater. The distribution of bacterioplankton tends to be high $\left(3.55 \times 10^{6}\right.$ cells $/ \mathrm{mL})$ on the surface $(0 \mathrm{~m})$, then declines at $4 \mathrm{~m}$ depth and then increase again near above the light compensation depth zone (Figure 2.A). Going further down to $20 \mathrm{~m}$ depth, the number of total bacterioplankton is decreasing towards $2.5 \times 10^{4}$ cells $/ \mathrm{mL}$ (Figure $2 . \mathrm{A}$ ). Analysis of variance towards total bacterioplankton counts showed that the numbers from one depth to another did not differ significantly (Table S2). This observation might be attributed to the mixing of the water column.

\section{Distribution and abundance of AAP bacteria}

The abundance of AAP bacteria in this study was determined using the copy number of pufM, a gene expressing photosystem-II protein subunit which is a signature of AAP bacteria community. Although homologous gene was also present in other purple bacteria not belonging to AAP bacteria, the occurrence of this gene in the oxygenated water column is unique to the latter community. The abundance of AAP bacteria measured was relatively small, ranging from 300 to 400 cells $/ \mathrm{mL}$ of seawater corresponding to $1-2 \%$ of total bacterioplankton (Figure 2.B-C). In terms of distribution, AAP bacteria were distributed quite similar to the total bacterioplankton by being more abundant on the surface water and decreasing along with the depth. However, near the light compensation depth zone, the number of AAP bacteria got higher compared to other depths. Similar to the total bacterioplankton, the variance of AAP bacteria counts among depths differed insignificantly (Table S3). This might also indicate that the same mixing causes the homogenous count of AAP bacteria in the water column.

\section{Water physicochemical parameters}

Similar to both total bacterioplankton and AAP bacteria, most water physicochemical parameters did not show significant differences between one depth to another (Figure 3; Table S4). This further confirms the occurrence of water column mixing on the coast of Siung. Dissolved oxygen, temperature, salinity, and $\mathrm{pH}$ showed steady levels with almost no value fluctuations. An interesting thing to note is that the parameter of inorganic nutrients, comprising nitrate, ammonium, phosphate, and sulfate displays little fluctuations, particularly between 4 to 6 meter depths. Nitrate, ammonium, and phosphate were slightly depleted at these depths indicating microbial utilization of these nutrients. The significantly high sulfate concentration might indicate a high surface run-off at the time of sampling. Since all of the measured water physicochemical parameters were distributed homogenously, it is quite difficult to draw relations between these parameters to total bacterioplankton or AAP bacteria. 

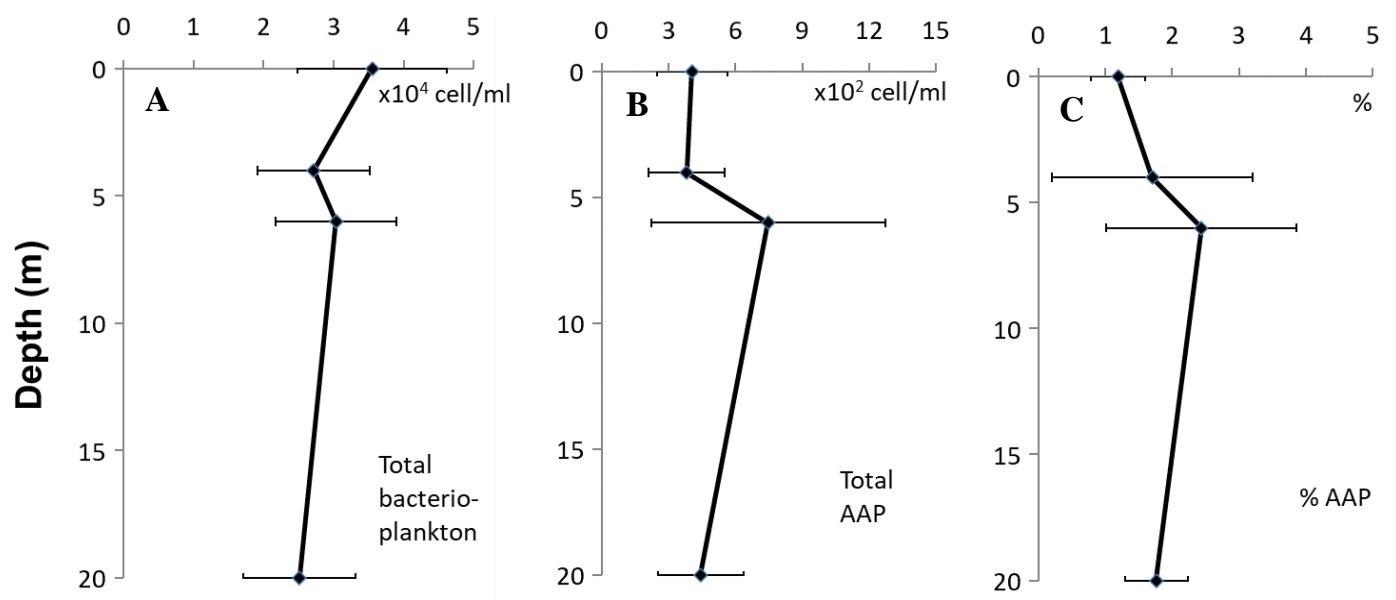

Figure 2. Distribution of total bacterioplankton (A), AAP bacteria (B) and percentage of AAP to total bacterioplankton (C) in Siung coastal water column at $0,4,6$, and 20 meters
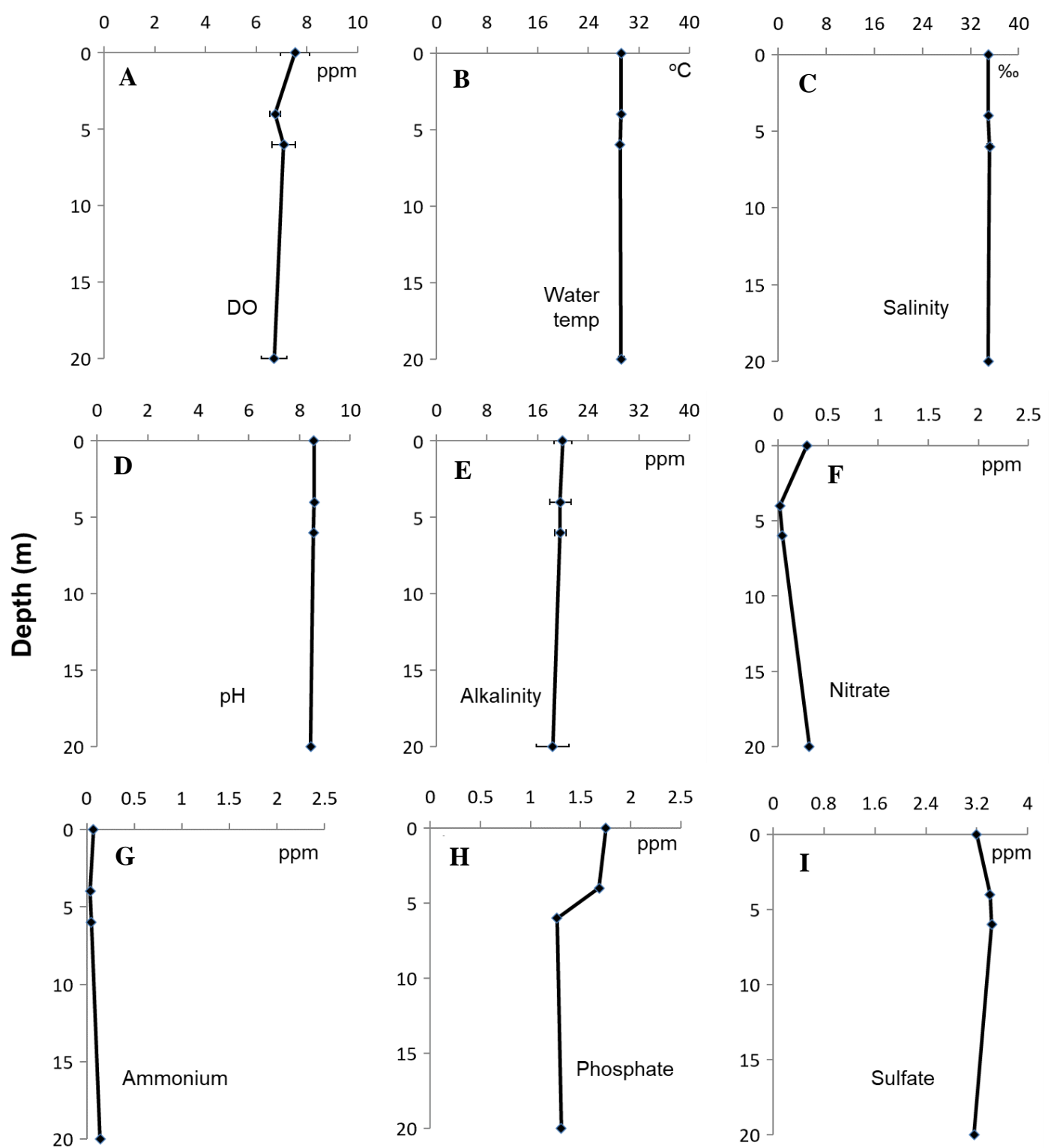

Figure 3. Distribution of water physicochemical parameters of Siung coastal zone water column comprising: dissolved oxygen (DO) (A), temperature (B), salinity (C), $\mathrm{pH}(\mathrm{D})$, alkalinity $(\mathrm{E})$, nitrate $(\mathrm{F})$, ammonium $(\mathrm{G})$, phosphate $(\mathrm{H})$ and sulfate (I). All parameters were measured from water column at $0,4,6$, and 20-meter depths 


\section{Discussion}

The percentage of AAP bacteria which only comprised $1-2.5 \%$ of total bacterioplankton in Siung water was considered low compared to similar data in other oceans. This percentage was similar to the low-end value of Northwest Atlantic (Sieracki et al. 2006) and North Pacific (Cottrell et al. 2006) oceans as well as Mediterranean sea (Hojerová et al. 2011). These similarities might imply that the distribution and abundance of both total bacterioplankton and AAP bacteria communities might be regulated by the same factors. Low water temperature or spring bloom is unlikely to be the causing factor since Siung water is located in the equator. Other factors such as shelf sea nature and its location facing Indian ocean make the water column in Siung coast undergoes vertical mixing at its upper layer (Purba et al. 2018). Such mixing is likely to create homogenous water temperature and nutrient content along the water column. Therefore, nutrient availability and predation are the most likely factor causing the low abundance of AAP bacteria in Siung coastal water.

Based on the requirement of carbon source, AAP bacteria are similar to heterotrophic bacteria. Therefore, their distribution and abundance tend to follow the fluctuations of dissolved organic matter (DOM) produced by phytoplankton. In turn, the distribution and abundance of phytoplankton are affected by inorganic nutrients such as nitrate and phosphate (Bradley et al. 2010a,b; Longnecker et al. 2010; Voss et al. 2011; Björkman et al. 2012; Lin et al. 2016; Reed et al. 2016). High nitrate and phosphate concentration but low $\mathrm{NO}_{3}{ }^{-} / \mathrm{PO}_{4}{ }^{3-}$ ratio in the water column is thought to be the factor causing both low AAP and bacterioplankton abundances (Weber and Deutsch 2010; Halm et al. 2012). This ratio, which is ten times lower than in the Pacific (Weber and Deutsch 2010), clear pictures that Siung water is $\mathrm{NO}_{3}$-limited.

Predation by nanoplanktons is likely to decrease the abundance of AAP bacteria even further in addition to affecting its distribution (Sanders and Gast 2012; Hisatugo et al. 2014; Batani et al. 2016). Studies on grazing of AAP bacteria by various nanoflagellate and nanociliate in marine and freshwater ecosystems had shown a higher preference towards AAP bacteria compared to other bacterial communities (Unrein et al. 2014; Garcia-Chaves et al. 2015; Rocke et al. 2015). The process of capturing, ingesting, and metabolizing the bacterial prey are entirely aerobic which consumes dissolved oxygen. This might indicate that the low count of AAP bacteria along with low DO level at $4 \mathrm{~m}$ depth is indicating AAP bacteria predation by nanoplankton. The predator preference for AAP bacteria might be related to cell biovolume difference. AAP bacteria possess larger cell biovolume compared to other bacterioplankton (Sieracki et al. 2006; Lami et al. 2007) and this might be selectively preferred by nanoplankton community (Garcia-Chaves et al. 2015, 2016). More studies are needed to elucidate this top-down regulation of AAP bacteria and its implication to the overall microbial loop and its connection to the larger trophic food web on Siung coast.

\section{REFERENCES}

Achenbach LA, Carey J, Madigan MT. 2001. Photosynthetic and phylogenetic primers for detection of anoxygenic phototrophs in natural environments. Appl Environ Microbiol 67 (7): 2922-2926. DOI: 10.1128/AEM.67.7.2922-2926.2001

Batani G, Pérez G, Martínez de la Escalera G, Piccini C, Fazi S. 2016. Competition and protist predation are important regulators of riverine bacterial community composition and size distribution. J Freshwater Ecol 31: 609-623. DOI: 10.1080/02705060.2016.1209443.

Béjà O, Suzuki MT, Heidelberg JF, Nelson WC, Preston CM, Hamada T, Eisen JA, Fraser CM, DeLong EF. 2002. Unsuspected diversity among marine aerobic anoxygenic phototrophs. Nature 415: 630-633. DOI: $10.1038 / 415630$ a.

Björkman K, Duhamel S, Karl D. 2012. Microbial group-specific uptake kinetics of inorganic phosphate and adenosine-5'-triphosphate (ATP) in the North Pacific Subtropical Gyre. Front Microbiol 3: 189. DOI: 10.3389/fmicb.2012.00189.

Boeuf D, Cottrell MT, Kirchman DL, Lebaron P, Jeanthon C. 2013. Summer community structure of aerobic anoxygenic phototrophic bacteria in the western Arctic Ocean. FEMS Microbiol Ecol 85 (3): 417-432. DOI: 10.1111/1574-6941.12130.

Boeuf D, Humily F, Jeanthon C. 2014. Diversity of Arctic pelagic bacteria with an emphasis on photoheterotrophs: A review. Biogeosciences 11: 3309-3322. DOI: 10.5194/bg-11-3309-2014.

Bradley PB, Lomas MW, Bronk DA. 2010a. Inorganic and organic nitrogen use by phytoplankton along Chesapeake Bay, measured using a flow cytometric sorting approach. Estuaries Coasts 33: 971984. DOI: $10.1007 / \mathrm{s} 12237-009-9252-\mathrm{y}$.

Bradley PB, Sanderson MP, Frischer ME, Brofft J, Booth MG, Kerkhof LJ, Bronk DA. 2010b. Inorganic and organic nitrogen uptake by phytoplankton and heterotrophic bacteria in the stratified MidAtlantic Bight. Estuarine Coastal Shelf Sci 88: 429-441. DOI: 10.1016/j.ecss.2010.02.001.

Cottrell MT, Mannino A, Kirchman DL. 2006. Aerobic anoxygenic phototrophic bacteria in the Mid-Atlantic Bight and the North Pacific Gyre. Appl Environ Microbiol 72 (1): 557-564. DOI: 10.1128/AEM.72.1.557-564.2006.

Csotonyi JT, Stackebrandt E, Swiderski J, Schumann P, Yurkov V. 2011. Chromocurvus halotolerans gen. nov., sp. nov., a gammaproteobacterial obligately aerobic anoxygenic phototroph, isolated from a Canadian hypersaline spring. Arch Microbiol 193 (8): 573-582. DOI: 10.1007/s00203-011-0698-5.

Du H, Jiao N, Hu Y, Zeng Y. 2006. Real-time PCR for quantification of aerobic anoxygenic phototrophic bacteria based on pufM gene in marine environment. J Exp Mar Biol Ecol 329: 113-121. DOI: 10.1016/j.jembe.2005.08.009

Ferrera I, Gasol JM, Sebastián M, Hojerová E, Kobížek M. 2011. Comparison of growth rates of aerobic anoxygenic phototrophic bacteria and other bacterioplankton groups in coastal Mediterranean waters. Appl Environ Microbiol 77: 7451-7458.

Ferrera I, Sánchez O, Kolářová E, Koblížek M, Gasol JM. 2017. Light enhances the growth rates of natural populations of aerobic anoxygenic phototrophic bacteria. ISME J 11 (10): 2391-2393. DOI: 10.1038/ismej.2017.79.

Garcia-Chaves MC, Cottrell MT, Kirchman DL, Derry AM, Bogard MJ, Del Giorgio PA. 2015. Major contribution of both zooplankton and protists to the top-down regulation of freshwater aerobic anoxygenic phototrophic bacteria. Aquatic Microb Ecol 76: 71-83.

Garcia-Chaves MC, Cottrell MT, Kirchman DL, Ruiz-González C, del Giorgio PA. 2016. Single-cell activity of freshwater aerobic anoxygenic phototrophic bacteria and their contribution to biomass production. ISME J 10: 1579-1588. DOI: 10.1038/ismej.2015.242.

Graham ED, Heidelberg JF, Tully BJ. 2018. Potential for primary productivity in a globally-distributed bacterial phototroph. ISME J 12: 1861-1866. DOI: 10.1038/s41396-018-0091-3.

Halm H, Lam P, Ferdelman TG, Lavik G, Dittmar T, LaRoche J, D'Hondt S, Kuypers MMM. 2012. Heterotrophic organisms dominate nitrogen fixation in the South Pacific Gyre. ISME J 6 (6): 1238-1249. DOI: 10.1038/ismej.2011.182.

Hisatugo KF, Mansano AS, Hayashi LH, Regali-Seleghim MH. 2014. Ingestion of bacteria in a eutrophic subtropical reservoir pond with food web mainly controlled by zooplankton grazing. Limnologica 44 : 98-106. DOI: 10.1016/j.limno.2013.08.002. 
Hojerová E, Mašín M, Brunet C, Ferrera I, Gasol JM, Koblížek M. 2011. Distribution and growth of aerobic anoxygenic phototrophs in the Mediterranean sea. Environ Microbiol 13 (10): 2717-2725. DOI: 10.1111/j.1462-2920.2011.02540.x

Hördt A, López MG, Meier-Kolthoff JP, Schleuning M, Weinhold L-M, Tindall BJ, Gronow S, Kyrpides NC, Woyke T, Göker M. 2020. Analysis of 1,000+ type-strain genomes substantially improves taxonomic classification of Alphaproteobacteria. Front Microbiol 11: 468. DOI: 10.3389/fmicb.2020.00468.

Jung Y-T, Park S, Lee J-S, Yoon J-H. 2017. Roseobacter ponti sp. nov., isolated from seawater. Intl J Syst Evol Microbiol 67 (7): 2189-2194. DOI: 10.1099/ijsem.0.001922.

Kirchman DL. 2018. Processes in Microbial Ecology $2^{\text {nd }}$ Edition. Oxford University Press, Oxford, England.

Kirchman DL, Hanson TE. 2013. Bioenergetics of photoheterotrophic bacteria in the oceans. Environ Microbiol Rep 5 (2): 188-199. DOI: 10.1111/j.1758-2229.2012.00367.x

Kirchman DL, Stegman MR, Nikrad MP, Cottrell MT. 2014. Abundance, size, and activity of aerobic anoxygenic phototrophic bacteria in coastal waters of the West Antarctic Peninsula. Aquatic Microb Ecol 73: 41-49.

Kolber ZS, Van Dover CL, Niederman RA, Falkowski PG. 2000 Bacterial photosynthesis in surface waters of the open ocean. Nature 407 (6801): 177-179. DOI: 10.1038/35025044.

Kolber ZS, Plumley FG, Lang AS, Beatty JT, Blankenship RE, Van Dover CL, Vetriani C, Koblizek M, Rathgeber C, Falkowski PG. 2001. Contribution of aerobic photoheterotrophic bacteria to the carbon cycle in the ocean. Science 292: 2492-2495.

Lami R, Cottrell MT, Ras J, Ulloa O, Obernosterer I, Claustre H, Kirchman DL, Lebaron P. 2007. High abundances of aerobic anoxygenic photosynthetic bacteria in the South Pacific Ocean. App Environ Microbiol 73 (13): 4198-4205. DOI: 10.1128/AEM.02652-06

Lamy D, Jeanthon C, Cottrell MT, Kirchman DL, Van Wambeke F, Ras J, Dahan O, Pujo-Pay M, Oriol L, Bariat L, Catala P, Cornet-Barthaux V, Lebaron P. 2011. Ecology of aerobic anoxygenic phototrophic bacteria along an oligotrophic gradient in the Mediterranean Sea. Biogeosciences 8: 973-985.

Lin S, Litaker RW, Sunda WG. 2016. Phosphorus physiological ecology and molecular mechanisms in marine phytoplankton. J Phycol 52 (1): 10-36. DOI: 10.1111/jpy.12365.

Longnecker K, Lomas MW, Van Mooy BAS. 2010. Abundance and diversity of heterotrophic bacterial cells assimilating phosphate in the subtropical North Atlantic Ocean. Environ Microbiol 12 (10): 27732782. DOI: $10.1111 /$ j.1462-2920.2010.02247.x.

Muramatsu S, Kanamuro M, Sato-Takabe Y, Hirose S, Muramatsu Y, Takaichi S, Hanada S. 2020. Roseobacter cerasinus sp. nov., isolated from a fish farm. Intl J Syst Evol Microbiol 70 (9): 4920-4926. DOI: 10.1099/ijsem.0.004360.

Nagashima KVP, Verméglio A, Fusada N, Nagashima S, Shimada K, Inoue K. 2014. Exchange and complementation of genes coding for photosynthetic reaction center core subunits among purple bacteria. J Mol Evol 79 (1-2): 52-62. DOI: 10.1007/s00239-014-9634-z.

Park S, Chen S, Yoon J-H. 2020. Erythrobacter insulae sp. nov., isolated from a tidal flat. Intl J Syst Evol Microbiol 70 (3): 1470-1477. DOI: 10.1099/ijsem.0.003824

Park S, Jung Y-T, Choi SJ, Yoon J-H. 2017. Erythrobacter aquimixticola sp. nov., isolated from the junction between the ocean and a freshwater spring. Intl J Syst Evol Microbiol 67 (8): 2964-2969. DOI: 10.1099/ijsem.0.002055.

Parte AC. 2014. LPSN-list of prokaryotic names with standing in nomenclature. Nucleic Acids Res 42: D613-D616. DOI: 10.1093/nar/gkt1111.

Parte AC. 2018. LPSN - List of Prokaryotic names with Standing in Nomenclature (bacterio.net), 20 years on. Intl J Syst Evol Microbiol 68 (6): 1825-1829. DOI: 10.1099/ijsem.0.002786.

Purba NP, Pranowo WS, Faizal I, Adiwira H. 2018. Temperature-salinity stratification in the Eastern Indian Ocean using argo float. IOP Conf Ser Earth Environ Sci 162: 012010. DOI: 10.1088/17551315/162/1/012010.

Rand MC, Greenberg AE, Taras MJ. 1976. Standard Methods for The Examination of Water and Wastewater. American Public Health Association, Washington, D.C

Reed ML, Pinckney JL, Keppler CJ, Brock LM, Hogan SB, Greenfield DI. 2016. The influence of nitrogen and phosphorus on phytoplankton growth and assemblage composition in four coastal, southeastern USA systems. Estuarine Coastal Shelf Sci 177: 71-82. DOI: 10.1016/j.ecss.2016.05.002.
Ritchie AE, Johnson ZI. 2012. Abundance and genetic diversity of aerobic anoxygenic phototrophic bacteria of coastal regions of the pacific ocean. Appl Environ Microbiol 78 (8): 2858-2866. DOI: 10.1128/AEM.06268-11.

Rocke E, Pachiadaki MG, Cobban A, Kujawinski EB, Edgcomb VP. 2015. Protist community grazing on prokaryotic prey in deep ocean water masses. PLoS One 10 (4): e0124505. DOI: 10.1371/journal.pone.0124505.

Ruyitno. 1988. Perhitungan secara langsung bakteri laut menggunakan teknik mikroskop epifluoresens. Oseana 13 (1): 28-36. [Indonesian]

Sanders RW, Gast RJ. 2012. Bacterivory by phototrophic picoplankton and nanoplankton in Arctic waters. FEMS Microbiol Ecol 82 (2): 242-253. DOI: 10.1111/j.1574-6941.2011.01253.x.

Schwalbach MS, Fuhrman JA. 2005. Wide-ranging abundances of aerobic anoxygenic phototrophic bacteria in the world ocean revealed by epifluorescence microscopy and quantitative PCR. Limnol Oceanogr 50: 620-628.

Shiba T, Shioi Y, Takamiya KI, Sutton DC, Wilkinson CR. 1991. Distribution and physiology of aerobic bacteria containing bacteriochlorophyll-a on the east and west coasts of Australia. Appl Environ Microbiol 57: 295-300.

Shiba T, Simidu U. 1982. Erythrobacter longus gen. nov., sp. nov., an aerobic bacterium which contains bacteriochlorophyll-a. Intl J Syst Bacteriol 32: 211-217.

Sieracki ME, Gilg IC, Thier EC, Poulton NJ, Goericke R. 2006. Distribution of planktonic aerobic anoxygenic photoheterotrophic bacteria in the Northwest Atlantic. Limnol Oceanogr 51: 38-46.

Spalding MD, Fox HE, Allen GR, Davidson N, Ferdaña ZA, Finlayson M, Halpern BS, Jorge MA, Lombana A, Lourie SA, Martin KD, McManus E, Molnar J, Recchia CA, Robertson J. 2007. Marine Ecoregions of the World: A Bioregionalization of Coastal and Shelf Areas. BioScience 57: 573-583.

Stegman MR, Cottrell MT, Kirchman DL. 2014. Leucine incorporation by aerobic anoxygenic phototrophic bacteria in the Delaware estuary. ISME J 8 (11): 2339-2348. DOI: 10.1038/ismej.2014.75

Tang K-H, Tang Y, Blankenship R. 2011. Carbon metabolic pathways in phototrophic bacteria and their broader evolutionary implications. Front Microbiol 2: 165. DOI: 10.3389/fmicb.2011.00165.

Tomaš AV, Šantić D, Šolić M, Ordulj M, Jozić S, Šestanović S, Matić F, Kušpilić G, Gladan ŽN. 2019. Dynamics of aerobic anoxygenic phototrophs along the trophic gradient in the central Adriatic Sea. Deep-Sea Research Part II: Topical Studies in Oceanography 164: 112-121. DOI: 10.1016/j.dsr2.2019.06.001.

Unrein F, Gasol JM, Not F, Forn I, Massana R. 2014. Mixotrophic haptophytes are key bacterial grazers in oligotrophic coastal waters. ISME J 8 (1): 164-176. DOI: 10.1038/ismej.2013.132.

Voss M, Baker A, Bange HW, Conley D, Cornell S, Deutsch B, Engel A, Ganeshram R, Garnier J, Heiskanen A-S, Jickells T, Lancelot C, McQuatters-Gollop A, Middelburg J, Schiedek D, Slomp CP, Conley DP. 2011. Nitrogen processes in coastal and marine ecosystems. In Sutton MA, Howard CM, Erisman JW, Billen G, Bleeker A, Grennfelt P, van Grinsven H, Grizzetti B (eds.). The European Nitrogen Assessment. Cambridge University Press, Cambridge.

Weber TS, Deutsch C. 2010. Ocean nutrient ratios governed by plankton biogeography. Nature 467 (7315): 550-554. DOI: 10.1038/nature09403

Xing T, Liu Y, Wang N, Xu B, Liu K, Shen L, Gu Z, Guo B, Zhou Y, Liu H. 2017. Erythrobacter arachoides sp. nov., isolated from ice core. Intl J Syst Evol Microbiol 67 (10): 4235-4239. DOI: 10.1099/ijsem.0.002290.

Xu L, Sun C, Fang C, Oren A, Xu X-W. 2020. Genomic-based taxonomic classification of the family Erythrobacteraceae. Intl J Syst Evol Microbiol 70 (8): 4470-4495. DOI: 10.1099/ijsem.0.004293.

Yurkov VV. 2006. Aerobic Phototrophic Proteobacteria. In Dworkin M, Falkow S, Rosenberg E, Schleifer K, Stackebrandt E (eds.). The Prokaryotes. Springer, Nederland.

Zheng Q, Koblížek M, Beatty JT, Jiao N. 2013. Evolutionary divergence of marine aerobic anoxygenic phototrophic bacteria as seen from diverse organisations of their photosynthesis gene clusters. In: Zheng Q, Koblizek M, Beatty JT, Jiao N. (eds.). Genome Evolution of Photosynthetic Bacteria. Academic Press, New York.

Zhuang L, Liu Y, Wang L, Wang W, Shao Z. 2015. Erythrobacter atlanticus sp. nov., a bacterium from ocean sediment able to degrade polycyclic aromatic hydrocarbons. Intl J Syst Evol Microbiol 65 (10): 3714-3719. DOI: 10.1099/ijsem.0.000481. 
Table S1. DNA concentration from the extracted water samples

\begin{tabular}{|c|c|c|c|c|c|c|c|c|c|}
\hline Depth (m) & $n$ & Abs280 & Abs280/260 & $\begin{array}{c}\text { DNA conc } \\
\text { (ng/uL) }\end{array}$ & Depth (m) & $n$ & Abs280 & Abs280/260 & $\begin{array}{c}\text { DNA conc } \\
\text { (ng/uL) }\end{array}$ \\
\hline \multirow[t]{5}{*}{0} & $\mathrm{n} 1$ & 0.025 & 1.342 & 33.9 & 6 & $\mathrm{n} 1$ & 0.019 & 1.285 & 34.8 \\
\hline & $\mathrm{n} 2$ & 0.017 & 1.115 & 28.2 & & $\mathrm{n} 2$ & 0.019 & 1.109 & 25.8 \\
\hline & n3 & 0.014 & 1.073 & 19.2 & & n3 & 0.016 & 1.190 & 26.7 \\
\hline & $\mathrm{n} 4$ & 0.018 & 1.123 & 22.4 & & $\mathrm{n} 4$ & 0.02 & 1.182 & 26.9 \\
\hline & n5 & 0.012 & 1.055 & 21.6 & & n5 & 0.014 & 1.078 & 22.5 \\
\hline \multirow[t]{5}{*}{4} & $\mathrm{n} 1$ & 0.014 & 1.121 & 23.1 & 20 & $\mathrm{n} 1$ & 0.017 & 1.115 & 23.8 \\
\hline & $\mathrm{n} 2$ & 0.015 & 1.109 & 22.8 & & $\mathrm{n} 2$ & 0.016 & 1.132 & 26.5 \\
\hline & n3 & 0.015 & 1.191 & 24.9 & & n3 & 0.014 & 1.089 & 22.8 \\
\hline & $\mathrm{n} 4$ & 0.016 & 1.130 & 24.1 & & $\mathrm{n} 4$ & 0.015 & 1.077 & 23.5 \\
\hline & n5 & 0.014 & 1.085 & 23.1 & & n5 & 0.015 & 1.111 & 26.1 \\
\hline
\end{tabular}

Table S2. Total bacteria count using acridine orange direct count (AODC)

\begin{tabular}{|c|c|c|c|c|c|c|c|c|c|c|c|c|c|c|c|c|}
\hline \multirow{2}{*}{$\begin{array}{c}\text { Depth } \\
\text { (m) }\end{array}$} & \multirow[b]{2}{*}{ Replicate } & \multicolumn{12}{|c|}{ \# bacteria in field of view } & \multirow{2}{*}{$\begin{array}{c}\text { \# cell } \\
\text { per } \mathrm{mL} \\
\text { water }^{1}\end{array}$} & \multirow{2}{*}{$\begin{array}{c}\text { Avg } \\
\text { per } \\
\text { depth }^{2}\end{array}$} & \multirow{2}{*}{$\begin{array}{l}\text { SD per } \\
\text { depth }\end{array}$} \\
\hline & & 1 & 2 & 3 & 4 & 5 & 6 & 7 & 8 & 9 & 10 & Total & Avg & & & \\
\hline 0 & $\mathrm{n} 1$ & 5 & 5 & 5 & 7 & 14 & 18 & 12 & 8 & 8 & 12 & 94 & 9.4 & 38348 & $35492^{\mathrm{a}}$ & 10642 \\
\hline 0 & $\mathrm{n} 2$ & 8 & 6 & 8 & 13 & 8 & 9 & 10 & 19 & 19 & 13 & 113 & 11.3 & 46099 & & \\
\hline 0 & n3 & 3 & 4 & 3 & 7 & 11 & 10 & 17 & 11 & 11 & 22 & 99 & 9.9 & 40388 & & \\
\hline 0 & n4 & 13 & 6 & 6 & 6 & 9 & 11 & 7 & 9 & 9 & 9 & 85 & 8.5 & 34676 & & \\
\hline 0 & n5 & 6 & 2 & 3 & 2 & 3 & 3 & 7 & 4 & 8 & 6 & 44 & 4.4 & 17950 & & \\
\hline 4 & $\mathrm{n} 1$ & 7 & 8 & 10 & 7 & 8 & 9 & 11 & 7 & 9 & 8 & 84 & 8.4 & 34268 & $27170^{\mathrm{a}}$ & 8018 \\
\hline 4 & $\mathrm{n} 2$ & 8 & 5 & 4 & 8 & 11 & 5 & 9 & 5 & 9 & 9 & 73 & 7.3 & 29781 & & \\
\hline 4 & n3 & 7 & 13 & 5 & 5 & 8 & 9 & 9 & 8 & 10 & 7 & 81 & 8.1 & 33044 & & \\
\hline 4 & n4 & 2 & 2 & 3 & 2 & 3 & 4 & 8 & 4 & 3 & 5 & 36 & 3.6 & 14686 & & \\
\hline 4 & n5 & 3 & 4 & 3 & 7 & 5 & 6 & 8 & 9 & 6 & 8 & 59 & 5.9 & 24069 & & \\
\hline 6 & $\mathrm{n} 1$ & 8 & 4 & 7 & 9 & 4 & 5 & 6 & 5 & 9 & 7 & 64 & 6.4 & 26109 & $30352^{\mathrm{a}}$ & 8618 \\
\hline 6 & $\mathrm{n} 2$ & 7 & 6 & 4 & 6 & 6 & 6 & 8 & 4 & 6 & 5 & 58 & 5.8 & 23661 & & \\
\hline 6 & n3 & 3 & 7 & 8 & 2 & 2 & 4 & 16 & 7 & 5 & 7 & 61 & 6.1 & 24885 & & \\
\hline 6 & $\mathrm{n} 4$ & 5 & 15 & 8 & 9 & 7 & 8 & 16 & 11 & 11 & 19 & 109 & 10.9 & 44467 & & \\
\hline 6 & n5 & 10 & 8 & 9 & 7 & 9 & 10 & 6 & 7 & 6 & 8 & 80 & 8 & 32637 & & \\
\hline 20 & n1 & 8 & 4 & 4 & 4 & 7 & 7 & 12 & 8 & 8 & 6 & 68 & 6.8 & 27741 & $25130^{\mathrm{a}}$ & 7992 \\
\hline 20 & $\mathrm{n} 2$ & 4 & 6 & 7 & 9 & 3 & 4 & 6 & 6 & 7 & 7 & 59 & 5.9 & 24069 & & \\
\hline 20 & n3 & 8 & 7 & 8 & 8 & 12 & 11 & 8 & 9 & 9 & 11 & 91 & 9.1 & 37124 & & \\
\hline 20 & $\mathrm{n} 4$ & 4 & 2 & 5 & 10 & 2 & 4 & 2 & 7 & 7 & 8 & 51 & 5.1 & 20806 & & \\
\hline 20 & n5 & 3 & 2 & 5 & 5 & 6 & 4 & 3 & 4 & 3 & 4 & 39 & 3.9 & 15910 & & \\
\hline
\end{tabular}

Note: ${ }^{1}$ based on the formula: $(\mathrm{n} \times(\mathrm{A} 1 / \mathrm{A} 2) \times(1 / \mathrm{V})$, where $\mathrm{n}$ : average of cell count (column O); A1: area of filter paper in contact with sample $\left(625 \mathrm{~mm}^{2}\right)$; A2: field of view area at $1000 \mathrm{x}$ magnification $\left(0.02405 \mathrm{~mm}^{2}\right)$; V: volume of filtered water $(\mathrm{mL}) .{ }^{2}$ based on ANOVA conducted on agricolae R-package. Same letters indicate a non-significant difference $(p \leq 0.05)$.

Table S3. AAP bacteria count using real time quantitative PCR

\begin{tabular}{|c|c|c|c|c|c|c|c|c|}
\hline $\begin{array}{c}\text { Depth } \\
\text { (m) }\end{array}$ & Replicate & $\mathbf{C q}$ & $\log C_{0}{ }^{1}$ & $\mathrm{C}_{0}$ & $\begin{array}{c}\text { DNA conc } \\
(\mathrm{ng} / \mathrm{uL})\end{array}$ & $\begin{array}{l}\text { AAP bacteria } \\
{\text { (cell } / \mathrm{mL})^{2}}^{2}\end{array}$ & $\begin{array}{l}\text { Total bacteria } \\
(\text { cell } / \mathrm{mL})^{3}\end{array}$ & \% AAP \\
\hline 0 & $\mathrm{n} 1$ & 35.3237 & 1.67808 & 47.6517 & 33.9 & 323 & 38348 & 0.84249 \\
\hline 0 & $\mathrm{n} 2$ & 33.7879 & 2.0196 & 104.616 & 28.2 & 590 & 46099 & 1.27992 \\
\hline 0 & n3 & 34.4729 & 1.86726 & 73.6655 & 19.2 & 283 & 40388 & 0.7004 \\
\hline 0 & $\mathrm{n} 4$ & 33.4091 & 2.10382 & 127.006 & 22.4 & 569 & 34676 & 1.64085 \\
\hline 0 & n5 & 34.7947 & 1.79571 & 62.4758 & 21.6 & 270 & 17950 & 1.50359 \\
\hline 4 & n1 & 34.9367 & 1.76413 & 58.0941 & 23.1 & 268 & 34268 & 0.78322 \\
\hline 4 & $\mathrm{n} 2$ & 34.5996 & 1.83909 & 69.0376 & 22.8 & 315 & 29781 & 1.0571 \\
\hline 4 & n3 & 33.9817 & 1.97649 & 94.731 & 24.9 & 472 & 33044 & 1.42765 \\
\hline 4 & n4 & 33.3266 & 2.12218 & 132.489 & 24.1 & 639 & 14686 & 4.3482 \\
\hline 4 & n5 & 35.3249 & 1.67781 & 47.6224 & 23.1 & 220 & 24069 & 0.91409 \\
\hline 6 & n1 & 33.1582 & 2.15962 & 144.418 & 34.8 & 1005 & 26109 & 3.84978 \\
\hline 6 & $\mathrm{n} 2$ & 33.1699 & 2.15701 & 143.552 & 25.8 & 741 & 23661 & 3.13052 \\
\hline 6 & n3 & 34.8571 & 1.78184 & 60.5117 & 26.7 & 323 & 24885 & 1.29849 \\
\hline 6 & $\mathrm{n} 4$ & 31.8928 & 2.441 & 276.058 & 26.9 & 1485 & 44467 & 3.33997 \\
\hline 6 & $\mathrm{n} 5$ & 35.5879 & 1.61932 & 41.6214 & 22.5 & 187 & 32637 & 0.57389 \\
\hline 20 & $\mathrm{n} 1$ & 33.1221 & 2.16765 & 147.112 & 23.8 & 700 & 27741 & 2.52425 \\
\hline 20 & $\mathrm{n} 2$ & 34.9468 & 1.76187 & 57.793 & 26.5 & 306 & 24069 & 1.27258 \\
\hline 20 & n3 & 33.3456 & 2.11794 & 131.202 & 22.8 & 598 & 37124 & 1.61158 \\
\hline 20 & $\mathrm{n} 4$ & 34.5575 & 1.84844 & 70.5414 & 23.5 & 332 & 20806 & 1.59352 \\
\hline 20 & n5 & 35.0230 & 1.74493 & 55.5817 & 26.1 & 290 & 15910 & 1.82358 \\
\hline
\end{tabular}

Note: ${ }^{1}$ based on linear regression equation $\mathrm{Cq}=-4.497(\log \mathrm{C} 0)+48.87$; standards for linear regression were taken from Du et al. (2006). ${ }^{2}$ based on the formula: (C0 x (A/B) x C) / V; where A: stock DNA conc, B: DNA amount used in qPCR, C: total vol of extracted DNA, V: total vol of filtered water. ${ }^{3}$ from Table S2. 
Table S4. Physico-chemical parameters of the water column

\begin{tabular}{|c|c|c|c|c|c|c|c|c|c|c|c|c|c|c|c|c|c|c|c|c|c|c|c|c|}
\hline \multirow{2}{*}{$\begin{array}{c}\text { Depth } \\
\text { (m) }\end{array}$} & \multirow{2}{*}{$\begin{array}{c}\text { Repli- } \\
\text { cate }\end{array}$} & \multicolumn{4}{|c|}{ Temperature } & \multicolumn{4}{|c|}{ Dissolved Oxygen } & \multicolumn{3}{|c|}{ Salinity (\%o) } & \multicolumn{3}{|c|}{ pH } & \multicolumn{4}{|c|}{ Alkalinity (P) } & \multicolumn{5}{|c|}{ Inorganic Nutrient (ppm) } \\
\hline & & Time & $\begin{array}{c}\text { Temp } \\
(\mathbf{C})\end{array}$ & Avg & SD & $\begin{array}{c}\text { Titr } \\
(\mathrm{mL})\end{array}$ & $\begin{array}{c}\text { DO } \\
\text { (ppm) }\end{array}$ & Avg & SD & $\begin{array}{c}\text { Salinity } \\
\text { (\%) }\end{array}$ & Avg & SD & pH & Avg & SD & $\begin{array}{c}\text { Titr } \\
(\mathrm{mL})\end{array}$ & $\begin{array}{l}\text { Alk-P } \\
(\mathbf{p p m})\end{array}$ & Avg & SD & $\mathrm{NO}_{3}^{-}$ & $\mathrm{NH}_{4}^{+}$ & $\mathrm{PO}_{4}{ }^{3-}$ & $\mathrm{SO}_{4}{ }^{2-}$ & $\mathbf{F e}$ \\
\hline \multirow[t]{5}{*}{0} & $\mathrm{n} 1$ & 7:53 & 29.0 & 29.20 & 0.274 & 1.84 & 7.36 & 7.54 & 0.573 & 35.00 & 35.00 & 0.000 & 8.52 & 8.57 & 0.031 & 0.1 & 20 & 19.60 & 1.673 & 0.2900 & 0.0740 & 1.75383 & 3198.2 & $<0.003$ \\
\hline & $\mathrm{n} 2$ & & 29.5 & & & 1.73 & 6.92 & & & 35.00 & & & 8.56 & & & 0.11 & 22 & & & & & & & \\
\hline & n3 & & 29.0 & & & 2.04 & 8.16 & & & 35.00 & & & 8.59 & & & 0.09 & 18 & & & & & & & \\
\hline & n4 & & 29.0 & & & 2.03 & 8.12 & & & 35.00 & & & 8.59 & & & 0.1 & 20 & & & & & & & \\
\hline & n5 & & 29.5 & & & 1.78 & 7.12 & & & 35.00 & & & 8.59 & & & 0.09 & 18 & & & & & & & \\
\hline \multirow[t]{5}{*}{4} & n1 & 7:46 & 29.0 & 29.20 & 0.274 & 1.69 & 6.76 & 6.75 & 0.212 & 35.00 & 35.00 & 0.000 & 8.58 & 8.59 & 0.017 & 0.1 & 20 & 20.00 & 1.414 & 0.0210 & 0.0380 & 1.686 & 3406.9 & $<0.003$ \\
\hline & $\mathrm{n} 2$ & & 29.0 & & & 1.64 & 6.56 & & & 35.00 & & & 8.56 & & & 0.1 & 20 & & & & & & & \\
\hline & n3 & & 29.5 & & & 1.75 & 7.00 & & & 35.00 & & & 8.59 & & & 0.09 & 18 & & & & & & & \\
\hline & $\mathrm{n} 4$ & & 29.5 & & & 1.73 & 6.92 & & & 35.00 & & & 8.60 & & & 0.11 & 22 & & & & & & & \\
\hline & n5 & & 29.0 & & & 1.63 & 6.52 & & & 35.00 & & & 8.60 & & & 0.1 & 20 & & & & & & & \\
\hline \multirow[t]{5}{*}{6} & $\mathrm{n} 1$ & 7:35 & 29.0 & 29.00 & 0.000 & 1.83 & 7.32 & 7.09 & 0.456 & 35.00 & 35.20 & 0.447 & 8.58 & 8.56 & 0.027 & 0.1 & 20 & 19.60 & 0.894 & 0.0440 & 0.0490 & 1.26517 & 3436.4 & $<0.003$ \\
\hline & $\mathrm{n} 2$ & & 29.0 & & & 1.66 & 6.64 & & & 35.00 & & & 8.54 & & & 0.1 & 20 & & & & & & & \\
\hline & n3 & & 29.0 & & & 1.69 & 6.76 & & & 36.00 & & & 8.59 & & & 0.1 & 20 & & & & & & & \\
\hline & $\mathrm{n} 4$ & & 29.0 & & & 1.94 & 7.76 & & & 35.00 & & & 8.53 & & & 0.09 & 18 & & & & & & & \\
\hline & n5 & & 29.0 & & & 1.74 & 6.96 & & & 35.00 & & & 8.54 & & & 0.1 & 20 & & & & & & & \\
\hline \multirow[t]{5}{*}{20} & $\mathrm{n} 1$ & $7: 26$ & 30.0 & 29.20 & 0.447 & 1.54 & 6.16 & 6.71 & 0.500 & 35.00 & 35.00 & 0.000 & 8.35 & 8.45 & 0.081 & 0.07 & 14 & 18.40 & 2.608 & 0.3120 & 0.1440 & 1.30587 & 3156.3 & $<0.003$ \\
\hline & n2 & & 29.0 & & & 1.55 & 6.20 & & & 35.00 & & & 8.38 & & & 0.1 & 20 & & & & & & & \\
\hline & n3 & & 29.0 & & & 1.72 & 6.88 & & & 35.00 & & & 8.48 & & & 0.09 & 18 & & & & & & & \\
\hline & $\mathrm{n} 4$ & & 29.0 & & & 1.78 & 7.12 & & & 35.00 & & & 8.50 & & & 0.1 & 20 & & & & & & & \\
\hline & n5 & & 29.0 & & & 1.8 & 7.20 & & & 35.00 & & & 8.54 & & & 0.1 & 20 & & & & & & & \\
\hline
\end{tabular}

